\title{
Botox in periodontics - Exploring new avenues
}

SADJ March 2021, Vol. 76 No. 2 p78 - p83

MS Reddy ${ }^{1}$, SR Shetty ${ }^{2}$, RM Shetty ${ }^{3}$, V Vannala ${ }^{4}$, SS Khazi ${ }^{5}$, ST Mohammed ${ }^{6}$

\section{ABSTRACT}

From a periodontal point of view, various factors contribute to facial aesthetics. In the recent past, studies have revealed that excessive gingival display is a factor that influences an individual' smile line. Some literature exists to support that more than excessive gingival display of more than $3 \mathrm{~mm}$ is considered unaesthetic and termed a 'gummy smile' (GS).

The prevalence of gummy smile' has been 10\% and to be more common in females. Gingival hyperplasia altered passive eruption, vertical maxillary excess, and upper-lip hypermobility can all result in excessive gingival display when a patient smile.

To select the correct treatment protocol, accurate diagnosis is essential. Various techniques have used to treat gummy smile which includes surgical and non-surgical methods. Recently nonsurgical method using Botulinum toxin gained polarity considering that the method is minimally invasive.

Keywords

Botulinum toxin, gummy smile, bruxism, dental implants, masseteric Hypertrophy.

Author affiliations:

1. Manchala S Reddy: MDS, College of Dentistry, Gulf Medical University, Al Jurf, 4184, Ajman. United Arab Emirates. ORCID Number: 0000-0002-2441-6479

2. Shishir R Shetty: $P h D$, College of Dental Medicine, University of Sharjah, United Arab Emirates.

ORCID Number: 0000-0002-8097-6024

3. Raghavendra M Shetty: $P h D$, College of Dentistry, Ajman University, Ajman. United Arab Emirates. ORCID Number: 0000-0003-1209-7295

4. Venkataramana Vannala: $P h D$, College of Dentistry, Gulf Medical University, Al Jurf, Ajman. United Arab Emirates. ORCID Number: 0000-0001-7075-7883

5. Shakeel S Khazi: MDS, College of Dentistry, Gulf Medical University, Al Jurf, Ajman. United Arab Emirates. ORCID Number: 0000-0001-7018-7550

6. Shoiab T Mohammed: MDS, College of Dentistry, Gulf Medical University, Al Jurf, 4184, Ajman. United Arab Emirates. ORCID Number: 0000-0001-7077-4202

Corresponding author: Manchala S Reddy

College of Dentistry, Gulf Medical University,

Al Jurf, 4184, Ajman. United Arab Emirates.

Email: seshaperio5@gmail.com

Author contributions:

Manchala S Reddy: Principal author - 20\%

Shishir R Shetty: Second author - 20\%

Raghavendra M Shetty: Third author - 15\%

Venkataramana Vannala: Fourth author - 15\%

Shakeel S Khazi: Fifth author - 15\%

Shoiab T Mohammed: Sixth author - 15\%

\section{INTRODUCTION}

Over the last decade, facial cosmetic procedures have become more common in dental and periodontal practices. As patient expectations are rising, the demand for facial aesthetics have prompted an evolution in techniques that optimize aesthetics. It is hypothesized that the first impression is the lasting impression and dental beauty is a vital constituent of the impression.

As various emotions can be expressed through a smile, the need for a smile that glows are in demand. Dentofacial harmony relies on three important components teeth, lip, and gingival scaffold that governs the smile as it is a key factor for all expressions. Patient can encounter esthetic and the psychological problems due to gummy smile (GS) as it leads lack of once own self confidence to smile. ${ }^{1}$

Periodontics is a branch of dentistry that not only deals with the tooth supporting structure but also with facial aesthetics and the harmony between the lips, teeth, and gingiva. From a periodontal point of view, various gingival factors contribute to facial aesthetics. ${ }^{2,3}$

Studies support that excessive gingival display have an influence on an individual's smile line. ${ }^{2}$ There is a rise in minimally invasive cosmetic procedures and the use of Botox type $A$ (onabotulinumtoxinA) is one such procedure. ${ }^{4-6}$

Botulinum toxin is a lethal, naturally occurring neurotoxin produced by Clostridium botulinum. ${ }^{7}$ Presently seven serotypes of botulinum neurotoxin have been identified which include (serotypes A to G). ${ }^{8}$ Despite its lethal potential, the protein has other medical benefits.

Currently, there are three different forms of serotypes ie A botulinum toxin (Botox, Dysport, Xeomin) and only one form of type B botulinum toxin (MyoBloc) that have been commercialized for cosmetic and medical procedures. ${ }^{9}$

Botulinum toxin has been used within the medical and dental field for various purposes which include its application to facial esthetics, ${ }^{8}$ as an anti-wrinkle agents, ${ }^{10,11}$ and in the management of specific lacrimal gland disorders, ${ }^{12}$ chronic headaches, ${ }^{13}$ children with cerebal palsy, ${ }^{14}$ myofunctional pain and occlusal function, ${ }^{15}$ bruxisum, ${ }^{16}$ dental impants, ${ }^{17}$ gummy smile. ${ }^{18}$

The aim of the current review is to discuss the use of botulinum toxin (BTX) as an alternative treatment modality in treating gummy smile and its application in the field of periodontics. 
Botox and its applications in periodontics: BTX is used in the field of periodontics for the treatment of conditions, which include a gummy smile that defined as excessive gingival display of gingiva more than $2 \mathrm{~mm}$, bruxism, immediate loading implants, sialorrhea, masseteric hypertrophy and parafunctional habit such as pathologicclenching. ${ }^{18-20}$ The etiology for GS was categorized into three factors which include bone gum and muscles.

Bone lead to excess vertical maxilla, the gum in delayed passive dental eruption, and the muscles in hyperfunctioning upper lip elevators. ${ }^{2}$

\section{Diagnosis of gummy smile (GM)}

Correct diagnosis of GM is done by identifying the etiology with the help of medical and dental history that provide patient age and eruption stage of dentition along with contributing factors for GM. Followed by periodontal examination to measure width of attached gingiva, probing pocket depth and clinical attachment loss to rule out any pathologic and nonpathological changes in the architecture of the periodontium.

Later analysis of face done to evaluate vertical maxillary excess (VME) by cephalometric analysis. Lip analysis done both in static and dynamic posture to assess lip length, hypermobility, or both. Dentialveolar analysis is done to measure the interlabial gap by analyzing 3D position of the incisors during rest position. $0-4 \mathrm{~mm}$ is considered normal interlabial gap. ${ }^{21,22}$

\section{Mechanism of Action}

BTX inhibits neuromuscular transmission by blocking the extracellular release of acetylcholine thereby inhibiting signals to muscle cells which in turn leads to reduced muscle action or overall lack of muscle contraction as shown below. ${ }^{19}$

\section{Factors affecting Botox injections}

1. Dosage - Differs among females and males governed by lip muscle volume. ${ }^{23-25}$ (Table 1)

2. Precise injection of intramuscular BTX at Yonsei point. ${ }^{26}$ (Figure 1)

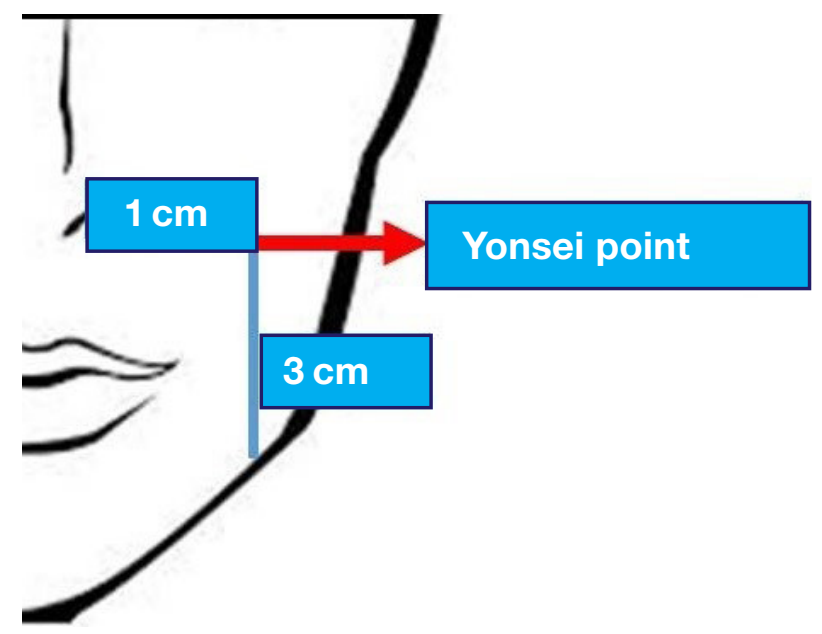

Figure 1. Schematic representation of BTX injection site.

\section{Side effects of Botox injections}

Though Botox use is minimally invasive, it still leads to certain side effects. They can be categorized as common side effects, improper injection technique and drug over dosage. ${ }^{25}$ Common side effects comprise pain, infection, inflammation, bruising and hematoma formation, loss of muscle strength and, muscle weakness as well as less commonly, nerve palsy. ${ }^{27}$

Improper injection technique could affect the smile symmetry and effect function manifesting as, difficulty in talking, mastication and/or drinking. Drug overdose might lead to a 'loose lip', dropping to beneath the level of the marginal gingiva, affecting teeth visibility during smiling..$^{28}$

\section{Uses of Botox in periodontics}

\section{Treatment of gummy smile}

'Gummy smile' is a term that refers to excessive maxillary gingival display more than $2 \mathrm{~mm}$ during smiling. Its prevalence has been reported as 10\% and most common in females aged 20-30 years. ${ }^{29,30}$ Etiology for GM vary from short or hyperactive upper lip muscles such as levator labii superioris (LLS), levator labii superioris alaeque nasii (LLAN, levator anguli oris (LAO), depressor septi (DP) and the zygomatic major (ZM) zygomatic minor (Zmi), or other factors such as altered passive eruption of teeth, dentoalveolar extrusion, vertical maxillary excess. Appropriate diagnosis will lead to effective treatment.

GS is diagnosed as low, moderate, and high based amount of gingiva exposed while smiling using Goldstein classification. ${ }^{25}$ Various techniques have used to treat gummy smile which includes surgical and non-surgical methods. Recently nonsurgical method using Botulinum toxin gained polarity considering that the method is minimally invasive. BTX is mainly used in patients with hyperactive upper 
lip elevator muscles which leads to flaccid paralysis of upper lip thus resulting in the mild gingival display. ${ }^{26,31}$ Site of Injection is considered as Yonsei site, which is a core of the triangle constituting LLS, Zmi, LLSAN. ${ }^{32,33}$

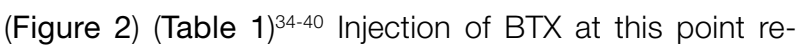
sults in muscle paralysis, that intern decrease upper lip lift due to decline in muscles contractability leading to less gingival display while smiling. ${ }^{25,38,41}$

\section{Treatment of Bruxism}

The temporalis and masseter muscles are muscles that may be affected in an individual with a bruxism habit. BTX can be used as a virtuous alternative treatment option for bruxism as it reduces the muscle contraction by its inhibitory action on acetylcholine release. ${ }^{42}$ It also relaxes temporalis and masseter muscle which provide all the power for bruxism.

It has an edge over other treatment options such as oral splint, behavioral approaches, and muscle relaxants in sleep bruxism cases when compared to conservative apprpoach. ${ }^{43-44}$ As its non in vase conservator approach as it reduces tooth wear and protects early implant loss. ${ }^{44}$

\section{In Dental Implantology}

There may be therapeutic benefit of BTX administration to the muscles of mastication in patients with dental implants as it may aid favorable osseointegration during the initial phase of healing. ${ }^{41}$ Implant failures occur due bruxism or due to excessive functional force. Odds ratio of implant failure has been shown to be 2.71 in bruxism patients vs. non-bruxers. Excessive functional force leads micro-fractures at the bone-implant interface as it exceeds the bone physiologic threshold. ${ }^{45}$

This can be prevented by injection of BTX type A to masticatory muscles. This leads to relaxation of masticatory muscles as well as relief the abnormal forces which results in better implant osseointegration as BTX weakens the muscle for a period of three to four months. ${ }^{41,46}$

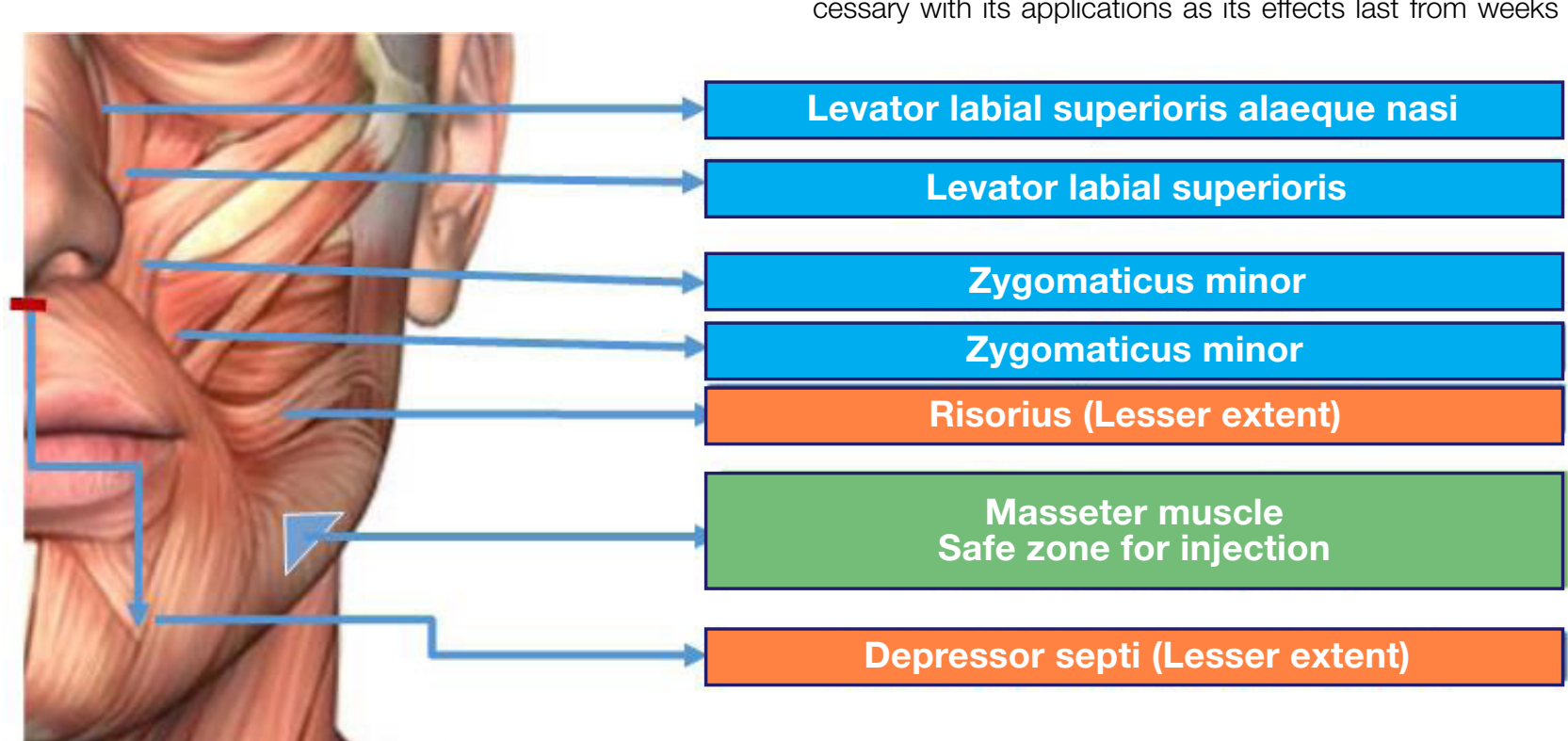

\section{Treatment of Sialorrhea}

Excessive salivation is termed Sialorrhea. Though various treatment methods are available, of late the use of BTX has gained attention. By injecting BTX into the parotid and submaxillary salivary glands, stimulation of the cholinergic receptors is impeded and thus reducing salivary flow. This technique is simple enough to use in patients with special needs with excessive salivation.47-49

\section{Treatment of Masseteric Hypertrophy}

Masseteric hypertrophy usually presents as bilateral soft swelling adjacent to the angle of the mandible, coupled with facial pain. This hypertrophy may manifest as facial disfigurement. Various treatment methods are available interventional technique such as BTX injections has been applied to this condition, with caution.41,50,51

\section{Contraindications}

1. Impractical patients.

2. An individual suffering from a neuromuscular malady like (myasthenia gravis, Eaton-Lambert syndrome).

3. Individual hypersensitive to BTX-A or BTX-B.

4. Patients under medication such as aminoglycosides, penicillamine, quinine, and calcium blockers that hamper conduction of neuromuscular impulses.

5. Women who are pregnant or lactating.

\section{CONCLUSION}

Botox can be used as an adjunct non-invasive, atraumatic technique to treat patients with a gummy smile, bruxism, drooling saliva, masseteric hypertrophy, pathological clenching and after immediate implant placement.

It is quite a simple procedure that offers an excellent alternative to other procedures with higher morbidity rates. It can meet the expectations of the patient and solve aesthetic problems without surgical intervention. However, every technique has its own added advantages and disadvantages so do with Botox. A word of caution is necessary with its applications as its effects last from weeks

Figure 2. Muscles involved in facial smile and site of injection of BTX. 


\begin{tabular}{|c|c|c|c|c|c|c|c|}
\hline S.No & Authors & Study Type & Condition & $\begin{array}{l}\text { Type and dose } \\
\text { of Botox }\end{array}$ & Muscles involved & $\begin{array}{l}\text { Adverse effect } \\
\text { reported }\end{array}$ & Results \\
\hline 1 & $\begin{array}{l}\text { Polo M } \\
2005^{28}\end{array}$ & Case Report & GS & $\begin{array}{l}\text { BTX-A }-0.25 \mathrm{U} \\
\text { per muscle } \\
\text { bilaterally }\end{array}$ & $\begin{array}{l}\text { LLS, LLSAN, and } \\
\text { at the overlap areas } \\
\text { of the LLS and Zmi } \\
\text { muscles. }\end{array}$ & Not reported & $\begin{array}{l}\text { Authors reported that } \\
\text { treatment modality was } \\
\text { effective, producing estheti- } \\
\text { cally acceptable smiles. }\end{array}$ \\
\hline 2 & $\begin{array}{l}\text { Polo M } \\
2008^{34}\end{array}$ & Prospective & GS & $\begin{array}{l}\text { BTA - A } \\
2.5 \mathrm{UI} / 0.1 \mathrm{~mL}\end{array}$ & $\begin{array}{l}\text { Yonsei point - LL- } \\
\text { SAN and LLS and } \\
\text { the LLS and Zmi }\end{array}$ & $\begin{array}{l}\text { Pain, twitching and } \\
\text { headache }\end{array}$ & $\begin{array}{l}\text { Mean gingival display had } \\
\text { declined from } 5.2 \mathrm{~mm} \\
(+/-1.4 \mathrm{~mm}) \text { to } 0.09 \mathrm{~mm} \\
(+/-1.06 \mathrm{~mm}) \text { in } 2 \text { weeks. } \\
24 \text { weeks, average gingival } \\
\text { display was } 2.9 \mathrm{~mm} \text {. }\end{array}$ \\
\hline 3 & $\begin{array}{l}\text { Mazzuco R } \\
2010^{35}\end{array}$ & Prospective & GS & $\begin{array}{l}\text { BTA - A } \\
2.5 \mathrm{UI} / 0.1 \mathrm{~mL}\end{array}$ & $\begin{array}{l}\text { LLSAN and LLS } \\
\text { and the LLS and } \\
\text { Zmi }\end{array}$ & Asymmetrical smile & $\begin{array}{l}\text { Authors reported general } \\
\text { average improvement of } \\
75.09 \% \text {. }\end{array}$ \\
\hline 4 & $\begin{array}{l}\text { Sucupira E } \\
2012^{3}\end{array}$ & Prospective & GS & $\begin{array}{l}\text { BTA - A } \\
3.1 \mathrm{UI} / 0.1 \mathrm{~mL}\end{array}$ & LLSAN & Not reported & $\begin{array}{l}\text { Authors reported average } \\
\text { satisfaction level of } 9.75 \text { on a } \\
10 \text {-point scale. }\end{array}$ \\
\hline 5 & $\begin{array}{l}\text { Somaiah S } \\
2013^{36}\end{array}$ & Prospective & GS & $2.5 \cup R$ & LLSAN, LLS, Zmi & Not reported & $\begin{array}{l}\text { Authors reported decrease in } \\
\text { the gingival display (mean } \\
75.09 \% \text { ). Mean gingival } \\
\text { display decreased from } 4.7 \\
\pm 1.06 \text { from the } 1 \text { st week to } \\
0.95 \pm 0.72 \text { in the second } \\
\text { week. After } 12 \text { weeks it was } \\
3.7 \pm 1.16 \mathrm{~mm}\end{array}$ \\
\hline 6 & $\begin{array}{l}\text { Suber JS } \\
2014^{4}\end{array}$ & Prospective & GS & $\begin{array}{l}\text { BTA - A } \\
2 \mathrm{UI} / 0.1 \mathrm{~mL}\end{array}$ & LLSAN, LLS & Not reported & $\begin{array}{l}\text { Authors reported } 85 \% \text { and } \\
83 \% \text { reduction in gingival dis- } \\
\text { play for both central incisor } \\
\text { and canines. Central incisor } \\
\text { displayed average reduction } \\
\text { in GS from } 4.89 \mathrm{~mm} \text { to } \\
0.75 \mathrm{~mm} \text { and canines from } \\
4.25 \mathrm{~mm} \text { to } 0.74 \mathrm{~mm} \text {. }\end{array}$ \\
\hline 7 & $\begin{array}{l}\text { Al-Fouzan AF } \\
2017^{37}\end{array}$ & In vivo study & GS & Botox type I & LLS, LLSAN & Not reported & $\begin{array}{l}\text { Authors reported clear re- } \\
\text { duction in gingival display } \\
\text { after } 2 \text { weeks with } 96.6 \% \\
\text { reduction in GS. }\end{array}$ \\
\hline 8 & $\begin{array}{l}\text { Pedron IG } \\
2018\end{array}$ & Case Report & GS & $2 \mathrm{UI} / 1.7 \mathrm{ml}$ & $\begin{array}{l}\text { Laterally to each } \\
\text { nostril. }\end{array}$ & Not reported & $\begin{array}{l}\text { Authors reported reduction } \\
\text { in GS. }\end{array}$ \\
\hline 9 & $\begin{array}{l}\text { Araujo JP } \\
2018^{38}\end{array}$ & Case report & GS & $\begin{array}{l}\text { BTXA } \\
2 \text { IU } \\
5 \text { IU }\end{array}$ & $\begin{array}{l}\text { LLS minor zygo- } \\
\text { maticus bilaterall }\end{array}$ & Not reported & $\begin{array}{l}\text { Authors observed a signif- } \\
\text { icant decrease of gingival } \\
\text { exposure }(4 \mathrm{~mm}) \text { after the } \\
\text { period of four injection } \\
\text { sessions in an overall } \\
\text { interval of } 20 \text { months. }\end{array}$ \\
\hline 10 & $\begin{array}{l}\text { Mostafa D } \\
2018^{18}\end{array}$ & Case report & GS & BTX A & $\begin{array}{l}4 \text { units were inject- } \\
\text { ed on each side of } \\
\text { the nasolabial fold, } \\
1 \mathrm{~cm} \text { lateral and } \\
\text { below the nasal ala } \\
\text { - Yonsei point }\end{array}$ & $\begin{array}{l}\text { Difficulty in } \\
\text { contracting her } \\
\text { lips during kissing }\end{array}$ & $\begin{array}{l}\text { Authors observed results that } \\
\text { was extremely significant, } \\
\text { as the exposed gingival area } \\
\text { became } 1 \mathrm{~mm} \text {, However, } \\
\text { after } 11 \text { weeks, the gingival } \\
\text { exposed distance started to } \\
\text { increase } 1-1.5 \mathrm{~mm} \text { returning } \\
\text { back to its post-surgical ap- } \\
\text { pearance after } 6 \text { months. }\end{array}$ \\
\hline 11 & $\begin{array}{l}\text { Duruel O } \\
2019^{39}\end{array}$ & Prospective & GS & BTA - A & $\begin{array}{l}\text { Yonsei point - } \\
\text { LLSAN and LLS } \\
\text { and the LLS } \\
\text { and Zmi }\end{array}$ & $\begin{array}{l}\text { No complications } \\
\text { reported }\end{array}$ & $\begin{array}{l}\text { Authors reported gingi- } \\
\text { val display for each tooth } \\
\text { between second premolars } \\
\text { was measured less than } 3 \\
\mathrm{~mm} \text {, and the percentage of } \\
\text { improvement for each case } \\
\text { was calculated } 100 \% \text {. }\end{array}$ \\
\hline 12 & $\begin{array}{l}\text { Al Wayli H - } \\
2019^{40}\end{array}$ & Prospective & GS & $(B T X-A)$ & Yonsei point & Not reported & $\begin{array}{l}\text { Authors reported that single } \\
\text { dose of BTX-A injected at } \\
\text { the Yonsei point was effec- } \\
\text { tive in the treatment of GS } \\
\text { and achieved better results } \\
\text { than multiple injections at } \\
\text { various sites. }\end{array}$ \\
\hline
\end{tabular}


to months. Controlled use of this therapy is more important rather than its radical use. As the area of periodontics is expanding so boundaries and treatment of periodontal conditions have shifted dramatically the focus of periodontal treatments with the advent of new techniques.

Botulinum toxin has certainly opened the scope of periodontics and is drawing periodontists worldwide to apply it into their clinical use. With proper training, periodontist will be proficient in providing these treatments to patients, to meet both for dental and cosmetic needs.

\section{References}

1. Garber AD, Salama AM. The essentials of a smile: Diagnosis and treatment. Perio 2000; 1996: 11: 18-28.

2. Nasr MW, Jabbour SF, Sidaoui JA, Haber RN, Kechichian EG. Botulinum Toxin for the Treatment of Excessive Gingival Display: A Systematic Review. Aesthet Surg J. 2016; 36(1): 82-8.

3. Sucupira E, Abramovitz A. A simplified method for smile enhancement: botulinum toxin injection for gummy smile. Plast Reconstr Surg. 2012;130(3): 726-28.

4. Suber JS, Dinh TP, Prince MD, Smith PD. On a botulinum toxin A for the treatment of a "gummy smile". Aesthet Surg J. 2014; 34(3): 432-7.

5. Ezquerra F, Berrazueta MJ, Ruiz-Capillas A, Arregui JS. New approach to the gummy smile. Plast Reconstr Surg. 1999; 104(4): 1143-50.

6. Chagas TF, Almeida NV, Lisboa CO, Ferreira DMTP, Mattos $\mathrm{CT}$, Mucha JN. Duration of effectiveness of Botulinum toxin type A in excessive gingival display: a systematic review and meta-analysis. Braz Oral Res. 2018; 32: e30.

7. Caya JG, Agni R, Miller JE. Clostridium botulinum and the Clinical Laboratorian: A detailed review of botulism, including biological warfare ramifications of botulinum toxin. Arch Pathol Lab Med 2004; 128: 653-62.

8. Kattimani V, Tiwari RVC, Gufran K, Wasan B, Shilpa PH, Khader AA. Botulinum Toxin Application in Facial Esthetics and Recent Treatment Indications. J Int Soc Prev Community Dent. 2019; 9(2): 99-105.

9. Silberberg N, Goldstein M, Smidt A. Excessive gingival display - etiology, diagnosis and treatment modalities. Quintessence Int. 2009; 40(10): 809-18.

10. Lim SH, Sun Y, Thiruvallur Madanagopal T, Rosa V, Kang L. Enhanced Skin Permeation of Anti-wrinkle Peptides via Molecular Modification. J Int Sci Rep. 2018; 25; 8(1): 1596-1600.

11. Singh S, Nair AG, Alam MS, Mukherjee B. Outcomes of lacrimal gland injection of botulinum toxin in functional versus nonfunctional epiphora. Oman J Ophthalmol. 2019; 12(2): 104-107.

12. Satriyasa BK. Botulinum toxin (Botox) A for reducing the appearance of facial wrinkles: a literature review of clinical use and pharmacological aspect. Clin Cosmet Investig Dermatol. 2019; 10: 12: 223-28.

13. Ryu JH, Shim JH, Yeom JH, Shin WJ, Cho SY, Jeon WJ. Ultrasound-guided greater occipital nerve block with botulinum toxin for patients with chronic headache in the occipital area: a randomized controlled trial. Korean $\mathrm{J}$ Anesthesiol. 2019; 72(5): 479-85.

14. Ross Raftemo AE, Mahendran A, Hollung SJ, Jahnsen RB, Lydersen S, Vik T et al. Use of botulinum toxin A in children with cerebral palsy. Tidsskr Nor Laegeforen. 2019; 24:139(8).

15. Jadhao VA, Lokhande N, Habbu SG, Sewane S, Dongare S, Goyal N. Efficacy of botulinum toxin in treating myofascial pain and occlusal force characteristics of masticatory muscles in bruxism. Indian J Dent Res. 2017; 28(5): 493-7.

16. Malcmacher L, Kosinski T.Bruxism, Botox, and Dental Implants. Dent Today. 2017 Apr; 36(4): 94,96-7.
17. Jadhao VA, Lokhande N, Habbu SG, Sewane S, Dongare $S$, Goyal N. Efficacy of botulinum toxin in treating myofascial pain and occlusal force characteristics of masticatory muscles in bruxism. Indian J Dent Res. 2017; 28(5): 493-7.

18. Mostafa D. A successful management of sever gummy smile using gingivectomy and botulinum toxin injection: A case report. Int J Surg Case Rep. 2018; 42: 169-74.

19. Azam A, Manchanda S, Thotapalli S, Kotha SB. Botox Therapy in Dentistry: A Review. J Int Oral Health. 2015; 7 (Suppl 2): $103-5$.

20. El Lee, NH Kim, RH Park, JB Park, TJ Ahn. Botulinum Toxin Type A for Treatment of Masseter Hypertrophy: Volumetric Analysis of Masseter Muscle Reduction over Time. Arch Aesthetic Plast Surg. 2016; 22(2): 79-86.

21. Pavone AF, Ghassemian M, Verardi S. Gummy smile and short tooth syndrome - Part 1: etiopathogenesis, classification, and diagnostic guidelines. Compend Contin Educ Dent 2016; 37(2): 102-7.

22. Dym H, Pierre $R 2^{\text {nd }}$. Diagnosis and Treatment Approaches to a "Gummy Smile". Dent Clin North Am. 2020; 64(2): 341-49.

23. Polo M. A simplified method for smile enhancement: botulinum toxin injection for gummy smile. Plast Reconstr Surg. 2013; 131(6): 934e-935e.

24. Garcia A, Fulton JE. Cosmetic denervation of the muscles of facial expression with botulinum toxin. A dose-response study. Dermatol Surg. 1996; 22(1): 39-43.

25. Botulinum Toxin in Dentistry, Diana Mostafa, Additional information is available at the end of the chapter. http://dx.doi. org/10.5772/intechopen.78950. Provisional chapter. DOI: 10. 5772/intechopen.78950. (C) 2016 The Author(s). Licensee InTech. This chapter is distributed under the terms of the Creative Commons. Additional information is available at the end of.

26. Hwang WS, Hur MS, Hu KS, Song WC, Koh KS, Baik HS et |al. Surface anatomy of the lip elevator muscles for the treatment of gummy smile using botulinum toxin. Angle Orthod. 2009; 79 (1): 70-7.

27. J. Niamtu, Cosmetic oral and maxillofacial surgery options. J Am Dent Assoc. 2000; 131(6): 756-64.

28. Bas B, Ozan B, Muglali M, Celebi N. Treatment of masseteric hypertrophy with botulinum toxin: a report of two cases, Med. Oral Patol Oral Cir Bucal. 2010; 15 (4): 649- 52.

29. Peck S, Peck L, Kataja M. The gingival smile line. Angle Orthodont. 1992; 62(2): 91-100.

30. Polo M. Botulinum toxin type $A$ in the treatment of excessive gingival display. Am J Orthod Dentofacial Orthop. 2005; 127(2): 214-8.

31. Van Zandijcke M, Marchau MM. Treatment of bruxism with botulinum toxin injections. J Neurol Neurosurg Psychiatry. 1990; 53(6): 530.

32. Cersosimo MG, Bertoti A, Roca CU,Micheli F. Botulinum toxin in a case of hemimasticatory spasm with severe worsening during pregnancy. Clin Neuropharmacol. 2004; 27(1): 6-8.

33. Blitzer A, Brin MF, Greene PE, Fahn S. Botulinum toxin injection for the treatment of oromandibular dystonia. Ann Otol Rhinol Laryngol. 1989; 98(2): 93-7.

34. Polo M. Botulinum toxin type A (Botox) for the neuromuscular correction of excessive gingival display on smiling (gummy smile). Am J Orthod Dentofacial Orthop. 2008; 133(2): 195-203.

35. Mazzuco R, Hexsel D. Gummy smile and botulinum toxin: a new approach based on the gingival exposure area. J Am Acad Dermatol. 2010; 63(6): 1042-51.

36. Sanju Somaiah MK, Muddaiah S, Shetty B, Vijayananda KM, Bhat M, Shetty PS. Effectiveness of botulinum toxin A, in unraveling gummy smile: A prospective clinical study. APOS Trends Orthod. 2013; 3: 54-8.

37. Al-Fouzan AF, Mokeem LS, Al-Sagat RT, Alfalah MA, Alharbi MA, Al-Samary AE. Botulinum Toxin for the Treatment of Gummy Smile. J Contemp Dent Pract. 2017; 18(6): 474-8. 
38. Pedron IG, Mangano A. Gummy Smile Correction Using Botulinum Toxin with Respective Gingival Surgery. J Dent Shiraz Univ Med Sci. 2018; 19(3): 248-52.

39. Duruel O, Ataman-Duruel ET, Tözüm TF, Berker E. Ideal Dose and Injection Site for Gummy Smile Treatment with Botulinum Toxin-A: A Systematic Review and Introduction of Case Study. Int J Periodontics Restorative Dent. 2019; 39(4): e167-e173.

40. Al Wayli $\mathrm{H}$. Versatility of botulinum toxin at the Yonsei point for the treatment of gummy smile. Int J Esthet Dent. 2019 14(1): 86-95.

41. Nayyar P, Kumar P, Nayyar PV, Singh A. BOTOX: Broadening the Horizon of Dentistry. J Clin Diagn Res. 2014; 8(12): ZE25-ZE29.

42. Asutay F, Atalay $\mathrm{Y}$, Asutay H, Acar AH. The Evaluation of the Clinical Effects of Botulinum Toxin on Nocturnal Bruxism. Pain Res Manag. 2017; 6264146.

43. Tan EK, Jankovic J. Treating severe bruxism with botulinum toxin. J Am Dent Assoc. 2000; 131: 211-6.

44. Tintner R, Jankovic J. Botulinum Toxin Type A in the Management of Oromandibular Dystonia and Bruxism. Scientific and Therapeutic Aspects of Botulinum Toxin. Lippincott Williams \& Wilkins, Philadelphia PA. 2002; 343-50.

45. Sadowsky SJ. Occlusal overload with dental implants: a review. Int J Implant Dent. 2019; 5(1): 29. Published 2019 Jul 23. doi:10.1186/s40729-019-0180-8
46. Mijiritsky E, Mortellaro C, Rudberg O, Fahn M, Basegmez C, Levin L. Botulinum Toxin Type A as Preoperative Treatment for Immediately Loaded Dental Implants Placed in Fresh Extraction Sockets for Full-Arch Restoration of Patients With Bruxism. J Craniofac Surg. 2016; 27(3): 668-70.

47. Sinha A, Hurakadli M, Yadav P. Botox and derma fillers: The twin-face of cosmetic dentistry. International Journal of Contemporary Dental and Medical Reviews. 2015; 1-4.

48. Chan KH, Liang C, Wilson P, Higgins D, Allen GC. Long-term safety and efficacy data on botulinum toxin type $A$ : an injection for sialorrhea. JAMA Otolaryngol Head Neck Surg. 2013; 139(2): 134-8.

49. Barbero P, Busso M, Artusi CA, De Mercanti S, Tinivella M, Veltri $A$ et al. Ultrasound-guided Botulinum Toxin-A Injections: A Method of Treating Sialorrhea. J Vis Exp 2016; 9: 117.

50. Fedorowicz Z, van Zuuren EJ, Schoones J. Botulinum toxin for masseter hypertrophy. Cochrane Database Syst Rev. 2013; 9(9): CD007510.

51. Al-Ahmad HT, Al-Qudah MA. The treatment of masseter hypertrophy with botulinum toxin type A. Saudi Med J. 2006; 27(3): 397-400

\section{NOTICE of the $21^{\text {st }}$ ANNUAL GENERAL MEETING (AGM)} of The South African Dental Association NPC (SADA)

Notice is hereby given that the $21^{\text {st }}$ Annual General Meeting of Members (AGM) of The South African Dental Association (SADA) NPC, will be held on Thursday, 3 June 2021 at $18 \mathrm{~h} 00$, which will be conducted virtually and electronically on this date through the Zoom virtual meeting platform or similar digital platform. The Agenda with any supporting documents for the meeting will be posted on the SADA website.

SADA is your Association and your voice counts.

\section{KC Makhubele}

Chief Executive Officer

March 2021

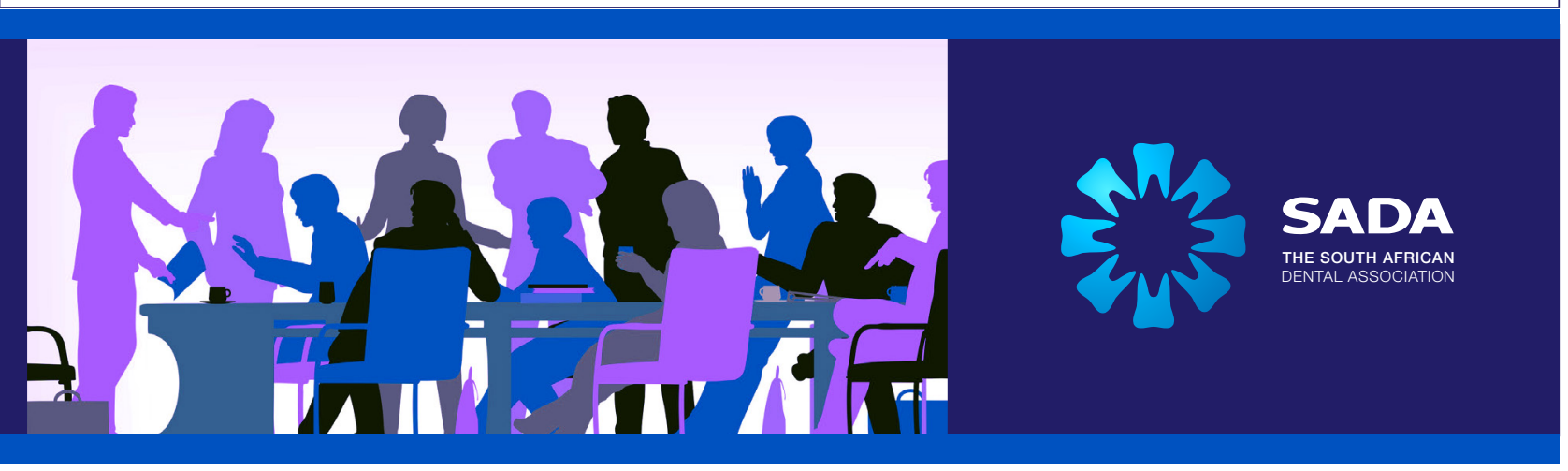

